\title{
The ecology of some free-living Ectocarpaceae
}

\author{
GeOrge Russell \\ Marine Biological Station, Port Erin, Isle of Man, England
}

\begin{abstract}
KURZFASSUNG: Die Ơkologie einiger freilebender Ectocarpaceae. Die Braunalgen Ectocarpus fasciculatus, E. siliculosus und Pilayella littoralis sind auch nach Loslösung von ihrem Substrat wachstumsfähig. Im Experiment wurden abgeschnittene Fadenstücke in einer Vorrichtung weiterkultiviert, die in Seewasser untergetaucht und so beschaffen war, daß die Lebensbedingungen so weit als möglich denen freilebender Algen entsprachen. Unter diesen Bedingungen bleiben alle drei Arten fertil und bilden uni- und plurilokuläre Sporangien aus. Diese sind jedoch kleiner, so daß weniger Schwärmer erzeugt werden als bei den festsitzenden Algen. Die losgelösten Pflanzen können sich auch vegetativ durch Fragmentation vermehren. Die Morphologie wird durch den freilebenden Zustand in folgender Weise verändert: Die Seitenzweige sind kürzer als bei den festgewachsenen Pflanzen und stehen in einem größeren Winkel zur Hauptachse. Das typische Verzweigungsmuster geht mehr oder weniger verloren; dies prägt sich bei E. fasciculatus am stärksten aus. Es wurde festgestellt, daß E. distortus und E. landsburgii freilebende Modifikationen von E. fasciculatus sind. Morphologische Zwischenformen entstehen, wenn freilebende Pflanzen sich mit ständig sublitoral lebenden Algen verflechten. Die interkalaren Sporangien von $P$. littoralis werden terminal oder subterminal in einer ähnlichen Stellung wie bei $P$. varia angelegt. Die Lebensdauer der freilebenden Algen dürfte zwei Monate erreichen, doch werden die Pflanzen unter natürlichen Verhältnissen offensichtlich schon früher an den Strand gespült.
\end{abstract}

\section{INTRODUCTION}

Early taxonomic works on marine algae often contain references to the existence of unattached plants which become cast ashore as drift weed. It is evident that the main interest of this material to the authors lay in its potential source of deep-water species for herbarium collections and there is little or no information on the precise origins of the plants. There is also little or no data on the length of time during which the material has been free from its substratum or on the effects of this state on the plants.

Ecological study of free-living marine algae did not begin seriously until the end of the last century. ReINKe (1892) and Schiller (1909) described the effects, mainly morphological, of the free-living state on several species of marine algae and the latter author described these in some detail together with an assessment of the new environmental factors experienced by the algae once they have assumed this condition. ColLINS (1914), on the basis of the geographical distribution of certain species on the N.E. coast of North America, estimated that some weed cast ashore at Eastham, Massachu- 
setts must have drifted there from Maine, a distance of at least 150 miles. His account unfortunately gives no information either on the time taken for, or on the results of, this journey.

Burrows (1958) studied the sublittoral algal population of Port Erin Bay, Isle of Man and observed the accumulation of a looselying algal community during the course of the summer. This community was of a temporary nature and its life span depended on the dates of the autumnal gales which quidkly threw the component species ashore.

It is evident from this that the approach to the study of free-living algae has been mostly synecological. Autecological accounts are infrequent and are, for the most part, concerned with members of the order Fucales. Recent outstanding examples of this type of work are those of Giвв (1957) on Ascophyllum nodosum on the W. coast of Scotland and Segawa et al. $(1959,1960)$ and Yoshida $(1963)$ on Sargassum spp. in the seas around Japan. Gris was concerned mainly with the morphological changes associated with the free-living state, the Japanese workers with the growth, longevity and distance covered by their material.

In general, as pointed out by Dixon (1965), information is sparse and this is also true in the particular case of the larger Ectocarpaceae. This is rather surprising because there are fairly frequent references in the literature to plants of Ectocarpus and related genera being torn by wave action from their substratum. It seems to be of near universal acceptance that this constitutes the end of their functional life. Collins (1914), referring to epiphytic species in general, declared that if torn from their host plants these would "speedily perish".

This investigation has been concerned with three species of Ectocarpaceae, Ectocarpus fasciculatus Harv., E. siliculosus (Dinlw.) Lyngb. and Pilayella littoralis (L.) KJELLM. and it set out to answer four questions. Can these species survive and grow in the unattached state? If so, for how long can they survive? What are the effects, if any, on the reproduction and form of the species? What role, if any, do these unattached plants have in the general ecology of the species?

The experimental work was carried out in the summers of 1965 and 1966 at the Marine Biological Station, Port Erin, Isle of Man.

\section{GROWTH OF UNATTACHED PLANTS}

This was assessed by collecting at random five plants of each species from the shore and mincing each plant into short lengths of filament by chopping with a razor. The excised pieces of filament were shaken up with about $10 \mathrm{cc}$ of filtered seawater and 4 or 5 drops of the resulting suspension were used as inoculum with about $110 \mathrm{cc}$ Erd-Schreiber culture medium, in the manner employed by Russell (1963). The cultures were contained in glass crystallising dishes receiving continuous fluorescent lighting of $110 \mu \mathrm{g} \mathrm{cal} / \mathrm{cm}^{2} \mathrm{sec}$ (1100 lux daylight equivalent) and a temperature of $10^{\circ} \mathrm{C}$. They were undisturbed for 14 days after which the experiment was ended.

Filament length was assessed before and after the experiment by putting one or two drops of each filament suspension on a microscope slide and measuring the length of ten pieces at random with a micrometer eyepiece. 
Table 1

Mean and individual percentage increase in length of excised filaments of Ectocarpus ssp. and Pilayella grown in culture for a period of fourteen days. Filament length (A) refers to that at the beginning of the experiment and (B) to that at the end

\begin{tabular}{|c|c|c|c|c|c|}
\hline Species & Plant & $\begin{array}{c}\text { Filament } \\
\text { length } \\
\text { in } m m(A)\end{array}$ & $\begin{array}{l}\text { Filament } \\
\text { length } \\
\text { in } m m(B)\end{array}$ & $\begin{array}{c}0 / 0 \\
\text { Increase } \\
\text { in length }\end{array}$ & $\begin{array}{l}\text { Mean } \% \\
\text { increase }\end{array}$ \\
\hline $\begin{array}{l}\text { Ectocarpus } \\
\text { fasciculatus }\end{array}$ & $\begin{array}{l}1 \\
2 \\
3 \\
4 \\
5\end{array}$ & $\begin{array}{l}0.27 \\
0.31 \\
0.31 \\
0.33 \\
0.31\end{array}$ & $\begin{array}{l}0.60 \\
0.69 \\
0.65 \\
0.73 \\
0.89\end{array}$ & $\begin{array}{l}122.2 \\
122.6 \\
109.7 \\
121.2 \\
187.1\end{array}$ & 132.6 \\
\hline $\begin{array}{l}\text { Ectocarpus } \\
\text { siliculosus }\end{array}$ & $\begin{array}{l}1 \\
2 \\
3 \\
4 \\
5\end{array}$ & $\begin{array}{l}0.37 \\
0.36 \\
0.32 \\
0.33 \\
0.28\end{array}$ & $\begin{array}{l}1.02 \\
0.88 \\
1.69 \\
0.78 \\
1.48\end{array}$ & $\begin{array}{l}175.7 \\
144.4 \\
428.1 \\
136.4 \\
428.6\end{array}$ & 262.6 \\
\hline $\begin{array}{l}\text { Pilayella } \\
\text { littoralis }\end{array}$ & $\begin{array}{l}1 \\
2 \\
3 \\
4 \\
5\end{array}$ & $\begin{array}{l}0.37 \\
0.29 \\
0.49 \\
0.37 \\
0.31\end{array}$ & $\begin{array}{l}1.24 \\
1.30 \\
1.21 \\
0.78 \\
0.92\end{array}$ & $\begin{array}{l}235.1 \\
348.3 \\
146.9 \\
110.8 \\
196.7\end{array}$ & 207.6 \\
\hline
\end{tabular}

The results of this experiment are given in Table 1 and from these it can be seen that all plants in every species demonstrated an ability to regenerate new tissue from the smallest excised pieces of filament. It would therefore seem reasonable to infer that the three species are at least potentially capable of further growth in nature after detachment from their substratum.

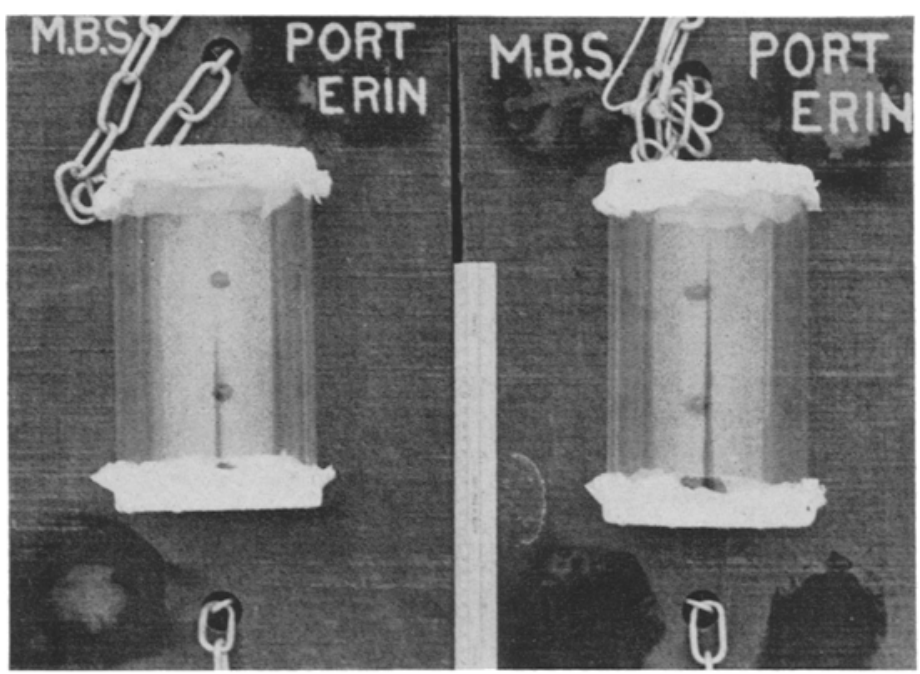

Fig. 1: Two of the experimental devices used in testing the effects of the free-living state on Ectocarpus spp. and Pilayella 


\section{LONGEVITY OF UNATTACHED PLANTS}

In order to confirm the findings from the culture experiment and to assess the longevity of unattached plants in nature the three species were tested in the apparatus shown in Figure 1. This consisted of an open-ended Perspex cylinder 9 inches in length, 5 inches in external diameter and $1 / 8$ inch in wall thickness. Each cylinder was bolted to a stout wooden (teak substitute) board. The ends of the cylinders were covered by a double layer of $1 / 32$ inch mesh nylon plankton netting sewn on by means of terylene twine.

Several plants of each species were collected from the shore and removed from their host plants (all were epiphytic on other algae). They were then placed in the cylinders, each species in its own apparatus, and the sewing of the plankton netting covers completed.

The apparatus was then attached by means of a 1 inch galvanised iron chain to the mooring chain of the starboard hand navigation buoy at the mouth of Port Erin Bay. The apparatus was shackled to the buoy chain at a depth of 5 or $6 \mathrm{~m}$ by a team of subaqua divers. The oscillation of the buoy caused continuous movement of water through the apparatus and resulted in conditions thought similar to those experienced by free-living plants (Fig. 2).

Ectocarpus fasciculatus and Pilayella littoralis were treated in this manner for 7 weeks and E. siliculosus for 5 weeks. Even after the longer period of time the plants were alive and apparently healthy although those of Pilayella were very worn and

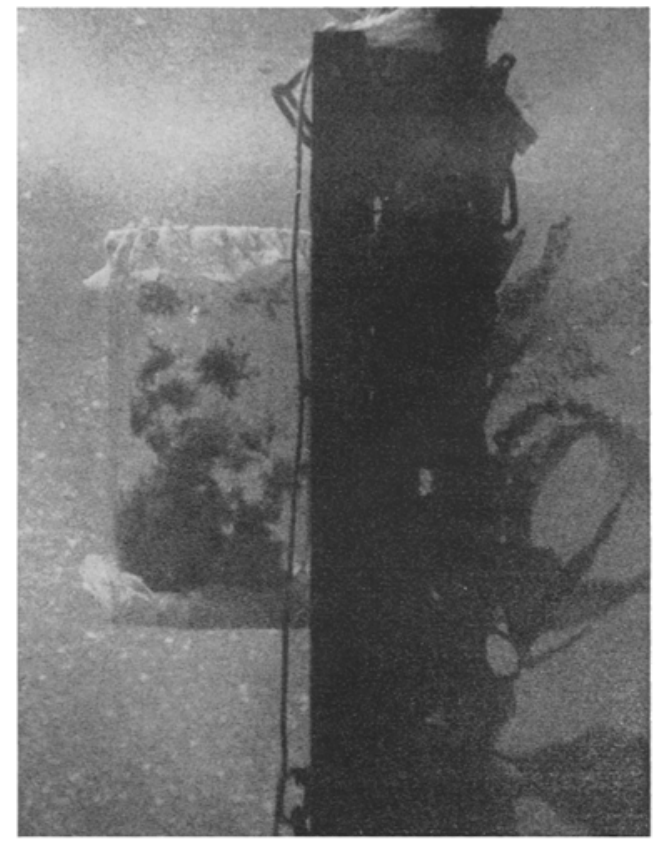

Fig. 2: As above but in situ on the mooring chain of a navigation buoy at Port Erin. Depth ca. 5 fathoms. (Photo: E. BRUN) 
some consisted of little other than the axial cable strands. It would therefore seem reasonable to infer that these three species are potentially capable of surviving in the unattached state for a period of at least two months. It was not possible to assess growth as the plants were very entangled with one another.

\section{EFFECTS ON REPRODUCTION AND FORM}

Free-living plants can propagate themselves by vegetative means as water movement, abrasion or other factors may cause pieces of filament to be broken off. They also continue to form both plurilocular and unilocular sporangia throughout their freeliving existence though these are usually smaller in size and less abundant than those on attached plants. The free-living state is associated therefore in these species with a considerably reduced fecundity.

The effects of the free-living state on plant form may be summarised as follows: (1) The angle of lateral branch emergence increases, up to $90^{\circ}$ or more. (2) New lateral branches tend to be short. (3) Branch succession becomes less clear or is lost altogether. (4) Sporangia are small in size and in Pilayella they tend to become terminal or subterminal in position very like those of $P$. varia KJeLlm. in Jaasund (1965).

These changes are depicted in Figure 3 and from this it can be seen that the most profound morphological response is found in the case of $E$. fasciculatus ( $\mathrm{F}$ and $\mathrm{C}$ ); $E$. siliculosus (A and $\mathrm{B}$ ) and $P$. littoralis (D and $\mathrm{E}$ ) are apparently less affected.

The type specimens of $E$. distortus CARM. ex Harv. in Hook. and E. landsburgii $H_{A R v}$. have been located at Trinity College, Dublin, Eire, and these show clearly the tangled appearance associated with free-living plants. The detailed morphology of these species has also shown them to correspond with Figure $3 \mathrm{C}$ and it has been suggested, Russell (1966) that E. distortus and E. landsburgii constitute free-living ecads of E. fasciculatus.

When fully developed, E. fasciculatus shows the most organised thallus structure of the three species under investigation and its most striking feature is the production of "fascicles" of branches at the tips of its main filaments (Fig. 3 F). It is possible that this indicates a degree of polarity not attained by E. siliculosus or P. littoralis. Thus, when the free-living state is acquired and proximal-distal orientation is lost, so too, is the branch pattern lost and those branches normally crowded together distally are now distributed randomly throughout the plant.

Plants of all three species may become detached from their substratum and then become entangled with attached permanent sublittoral species. In effect these plants have become reattached and their morphological features do not demonstrate the degree of change associated with truly free-living individuals. Also, it can be argued that these morphological changes are due to the mere processes of ageing and indeed KNIGHT (1929) has found that the angle of branch emergence increases in E. siliculosus with age. However it is uncommon for attached plants of any age to approach the degree of change shown in Figure 3. 


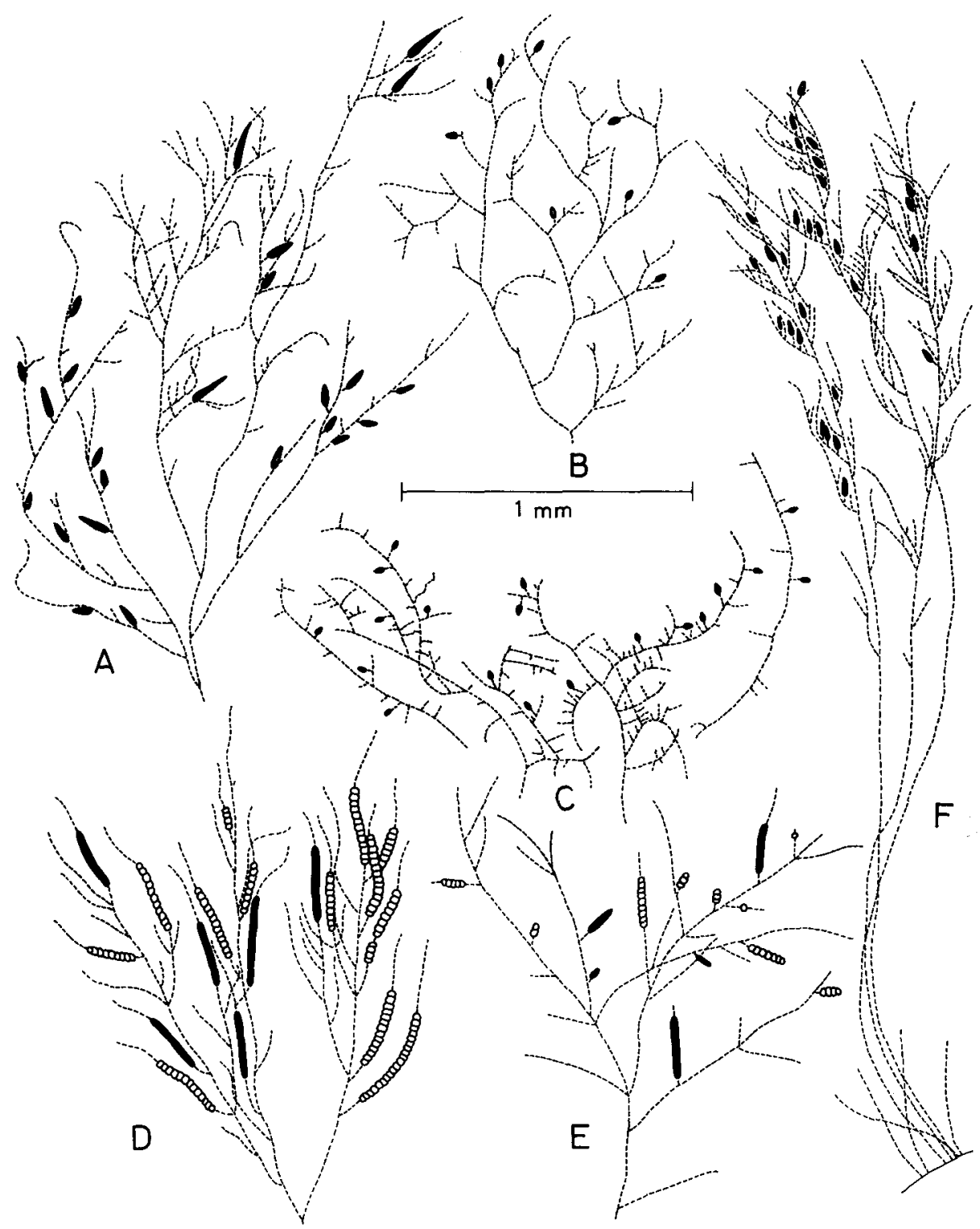

Fig. 3: Semidiagramatic representation of the main morphological effects of the free-living state on Ectocarpus fasciculatus Harv., E. siliculosus (DILLw.) Lyngr. and Pilayella littoralis (L.) KJelLm. Plurilocular sporangia (black) and unilocular sporangia (white) are shown as well as branch pattern. (A) Portion of thallus of typical attached E. siliculosus. (B) E. siliculosus after treatment in experimental apparatus (see Figs. 1 and 2). (C) E. fasciculatus after treatment in apparatus. (D) Typical attached $P$. littoralis. (E) $P$. littoralis after treatment in experimental apparatus. (F) Typical attached E. fasciculatus 


\section{ROLE OF FREE-LIVING PLANTS}

As was observed by Burrows (1958) the communities of free-living algae tend to build up in summer and are usually cast ashore by the first autumn gales. The freeliving plants of Ectocarpus and Pilayella are therefore not as a rule self-maintaining and their importance to the entire species populations is minor in comparison with that of the attached plants from which they originate. On the other hand the freeliving plants show persistent if reduced fertility during this phase of their existence and it must be assumed that they continue to make some contribution to the species populations. Once these plants have been cast ashore, however, they quickly die. Only in the case of free-living $P$. littoralis which sometimes survives for lengthy periods in the salt pans of certain salt marshes e.g. at the estuary of the River Eden, St. Andrews, Scotland, is death occasionally delayed.

In general, therefore, the ecological role of free-living Ectocarpus and Pilayella is a small one but locally such plants may occur in large numbers and, in the case of E. siliculosus, may reach large size. These plants may constitute an important sublittoral reservoir of fertile material at a time of the year when intertidal conditions can be very exacting.

\section{SUMMARY}

1. The work concerning the ecology of free-living marine algae is reviewed briefly.

2. The species examined in this investigation are the Phaeophyceae Ectocarpus fasciculatus, E. siliculosus and Pilayella littoralis.

3. From culture experiments using excised filament fragments as inoculum it is shown that these species can regenerate new tissue from detached pieces.

4. The longevity of the free-living plants in nature is assessed using the apparatus illustrated in Figures 1 and 2 and found to be in the region of two months.

5. Free-living plants may propagate vegetatively by fragmentation but they also continue to produce unilocular and plurilocular sporangia while in this condition. The fertility of the free-living plants is usually lower than in attached plants.

6. The main morphological effects of the free-living state are increase in angle of branch emergence, reduction in length of lateral branches and loss of branch pattern. This is accompanied by reduction in size of reproductive bodies. It is shown that $E$. distortus and E. landsburgii constitute free-living ecads of $E$. fasciculatus.

7. The role of free-living Ectocarpus and Pilayella in the entire species populations is thought to be minor but it is suggested that they might form a sublittoral reservoir of material in summer when intertidal conditions may be exacting.

\section{LITERATURE CITED}

Burrows, E. M., 1958. Sublittoral algal population in Port Erin Bay, Isle of Man. J. mar. biol. Ass. U. K. 37 (3), 687-703.

Coldins, F. S., 1914. Drifting algae. Rhodora 16 (1), 1-5. 
Dixon, P. S., 1965. Changing patterns of distribution in marine algae. In: The biological significance of climatic changes in Britain. Proceedings of a symposium held at the $\mathrm{R}$. Geogr. Soc., Lond., 29-30 Oct., 1964. Ed. by C. G. Johnson \& L. P. Smith. Acad. Pr., New York, 222 pp. (Symp. Inst. Biol. 14.)

Gibi, D. C., 1957. The free-living forms of Ascophyllum nodosum (L.) Le Jol. J. Ecol. 45 (1), 49-83.

JaAsund, E., 1965. Aspects of the marine algal vegetation of North Norway. Botanica gothoburg. 4, 1-174.

KNIGHT, M., 1929. Studies in the Ectocarpaceae. 2. The life-history and cytology of Ectocarpus siliculosus Dillw. Trans. R. Soc. Edinb. 56, 307-333.

Reinke, J., 1892. Über Gäste der Ostseeflora. Ber. dt. bot. Ges. 10, 4-12.

Russell, G., 1963. A study in populations of Pylaiella littoralis. J. mar. biol. Ass. U. K. 43 (2), 469-483.

- 1966. The genus Ectocarpus in Britain. 2. The free-living forms. J. mar. biol. Ass. U. K. 47, 233-250.

Schiller, J., 1909. Über Algentransport und Migrationsformationen im Meere. Int. Revue ges. Hydrobiol. Hydrogr. 2, 62-98.

Segawa, S., Sawada, T., Higaki, M. \& Yoshida, T., 1959a. Studies on the floating seaweeds. 1. Annual vicissitude of floating seaweeds in the Tsuyazaki region. Sci. Bull. Fac. Agric. Syushu Univ. 17 (1), 83-89.

- $-1959 \mathrm{~b}$. Studies on the floating seaweeds. 2. Floating seaweeds found in IkiTusima region. Sci. Bull. Fac. Agric. Kyushu Univ. 17 (3), 291-297.

$-\ldots-1959 \mathrm{c}$. Studies on the floating seaweeds. 3. Some considerations on the formation of the floating seaweeds. Sci. Bull. Fac. Agric. Kyushu Univ. 17 (3), 299-305.

$-\ldots+1960$. Studies on the floating seaweeds. 4. Growth of some sargassaceous algae based on the material secured from floating seaweeds. Sci. Bull. Fac. Agric. Kyushu Univ. $17(4), 429-435$.

- $-\&$ Yoshida, T., 1960. Studies on the floating seaweeds. 5. Seasonal change in amount of the floating seaweeds off the coast of Tsuyazaki. Sci. Bull. Fac. Agric. Kyushu Univ. 17 (4), 437-441.

Yosmida, T., 1963. Studies on the distribution and drift of the floating seaweeds. Bull. Tokai reg. Fish. Res. Lab. 23, 141-186.

\section{Discussion following the paper by RusseLL}

CRISP: Would Dr. RusSELL care to comment on the lack of reproductive capacity of the freeliving plants? It appears to be a general phenomenon since free living plants of Sargassum, Furcellaria and Ascopbyllum become wholly or partly sterile.

RusSELL: My material did not become sterile although the sporangia produced were very small and not abundant. Loss of fertility is a common phenomenon in unattached algae; I cannot explain it. 